\title{
Astyanax jordanensis (Ostariophysi: Characidae), a new species from the rio Iguaçu basin, Paraná, Brazil
}

\author{
Héctor S. Vera Alcaraz ${ }^{1,2}$, Carla S. Pavanelli ${ }^{1}$ and Vinicius A. Bertaco ${ }^{3}$
}

Astyanax jordanensis, new species, is described from the rio Jacu and rio das Torres, both tributaries to the lower rio Jordão, in the rio Iguaçu basin, Paraná, Brazil. The new species is a member of the A. scabripinnis species complex. Astyanax jordanensis differs from its congeners by several meristic and morphometric characters. Mature males possess bony hooks in the dorsal, pectoral, pelvic, and anal fins, and mature females have a few small bony hooks on the first rays of the anal fin. The presence of these bony hooks in females and the endemism of the ichthyofauna in the rio Jordão are discussed.

Astyanax jordanensis, espécie nova, é descrita do rio Jacu e do rio das Torres, ambos tributários do baixo rio Jordão na bacia do rio Iguaçu, Paraná, Brasil. A nova espécie é membro do complexo de espécies Astyanax scabripinnis. Astyanax jordanensis difere das congêneres por vários caracteres merísticos e morfométricos. Machos maduros apresentam ganchos ósseos nas nadadeiras dorsal, peitoral, pélvica e anal, e as fêmeas maduras possuem poucos ganchos ósseos pequenos nos primeiros raios da nadadeira anal. A presença destes ganchos nas fêmeas e o endemismo da ictiofauna no rio Jordão são discutidos.

Key words: Astyanax scabripinnis species complex, Endemism, Rio Jordão, Bony hooks.

\section{Introduction}

Astyanax Baird \& Girard, 1854 includes about one hundred species widespread from southern United States to central Argentina (Lima et al., 2003). The genus is currently delimited based on Eigenmann's definition $(1921,1927)$, which fails to diagnose a monophyletic entity (Rosen, 1972).

The ichthyofauna of the rio Iguaçu basin demonstrates a high degree of endemicity as a consequence of the Iguaçu Falls situated near the mouth of that river that serves as an effective barrier for fish dispersal. Six species of Astyanax occur in that drainage: A. altiparanae Garutti \& Britski, 2000; A. gymnogenys Eigenmann, 1911; A. ita Almirón, Azpelicueta \& Casciotta, 2002; A. leonidas Azpelicueta, Casciotta \& Almirón, 2002; A. totae Haluch \& Abilhoa, 2005 and A. varzeae Abilhoa \& Duboc, 2007. Except for A. altiparanae and A. leonidas, all remaining species are apparently endemic to the rio Iguaçu basin. Collecting efforts throughout the rio Iguaçu basin by the Núcleo de Pesquisas em Limnologia, Ictiologia e Aqüicultura (Nupélia) demonstrated that the tributary rio Jordão has its own endemic fish fauna including the species described as new in this paper.

\section{Material and Methods}

Counts and measurements were taken on the left side of specimens whenever possible, according to Fink \& Weitzman (1974), with the exception of the number of scale rows below the lateral line which followed Bertaco \& Malabarba (2001). Measurements were taken point to point with a caliper to the nearest $0.1 \mathrm{~mm}$. Measurements are expressed as percents of standard length (SL), except for subunits of the head, that are recorded as percents of head length (HL). Values in parentheses indicate the number of specimens with a particular count, and an asterisk indicates value of the holotype.

Osteological observations and counts of fin rays,

\footnotetext{
${ }^{1}$ PEA, Nupélia, Universidade Estadual de Maringá, Av. Colombo, 5790, 87020-900 Maringá, PR, Brazil. carlasp@nupelia.uem.br ${ }^{2}$ Faculdade de Biociências, Pontifícia Universidade Católica do Rio Grande do Sul, Av. Ipiranga, 6681, 90619-900 Porto Alegre, RS, Brazil. alcarazhsv@hotmail.com

${ }^{3}$ Universidade Federal do Rio Grande do Sul, Departamento de Zoologia, Av. Bento Gonçalves, 9500, 91501-970 Porto Alegre, RS, Brazil. vbertaco@gmail.com
} 
pterygiophores, vertebrae, supraneurals, and procurrent rays were done on radiographed and cleared and stained (c\&s) specimens prepared according to Taylor \& Van Dyke (1985). Counts of ribs and gill rakers were taken only in c\&s specimens. Vertebral counts included the four vertebrae of the Weberian apparatus, with the terminal compound centrum counted as a single element. Sexes of twenty specimens were determined by direct observation of the gonads, with the remaining specimens sexed based on sexual dimorphic characters. Lower and upper jaws of one c\&s specimen were prepared for Scanning Electronic Microscopy (SEM) analysis.

Institutional abbreviations are as listed at http:// research.calacademy.org/research/ichthyology/catalog/ abtabr.html, with addition of Copel (Companhia Paranaense de Energia).

\section{Results}

\section{Astyanax jordanensis, new species}

Figs. 1-2

Holotype. MZUSP 99137, 47.7 mm SL, male, Brazil, Paraná, município de Candói, rio Iguaçu basin, middle rio Jacu (25³7’S 5203’W), 23 Aug 1995, Nupélia \& Copel.
Paratypes. All from Brazil, Paraná, rio Iguaçu basin. MCP 41914 10, 58.7-68.6 mm SL; MHNCI 11714, 10, 31.5-63.0 mm SL (2, 60.7-62.9 mm SL); MZUSP 99138, 12, 42.7-76.1 mm SL; NUP 1681, 27, 23.0-68.2 mm SL (13, 39.2-68.2 mm SL); NUP 5242, 1 c\&s, $47.7 \mathrm{~mm}$ SL; all collected with holotype. MCP 41915, 4, 42.647.0 mm SL (1 c\&s); NUP 5245, 1 c\&s, 47.8 mm SL; NUP 5248, 3, 42.3-45.1 mm SL; all from município de Candói, upper rio Jacu, 23 Aug 1995, Nupélia \& Copel. NUP 5251, 4, 67.0-72.0 mm SL, município de Reserva do Iguaçu, rio das Torres, 25 Sep 1995, Nupélia. NUP 5252, 1, 68.5 mm SL, município de Reserva do Iguaçu, rio das Torres, 22 Jan 1996, Nupélia.

Diagnosis. Astyanax jordanensis fits the definition of the Astyanax scabripinnis species complex of Bertaco \& Lucena (2006), which are: body deepest and heaviest in area proximate to middle of pectoral fins, head heavy, snout short and abrupt by tapering, body shallower than $41 \%$ of SL, anal fin with 13-21 branched rays, presence of one or two humeral spots, and a dark midlateral body stripe extending to the tip of the middle caudal-fin rays. The new species differs from congeners of the $A$. scabripinnis species complex by having fewer branched anal-fin rays [13-17 vs. more than 17 in A. ita; A. laticeps (Cope, 1894); A. ojiara Azpelicueta \& Garcia, 2000; A. paris Azpelicueta, Almirón \& Casciotta, 2002; A. scabripinnis (Jenyns, 1842); and A. troya Azpelicueta,

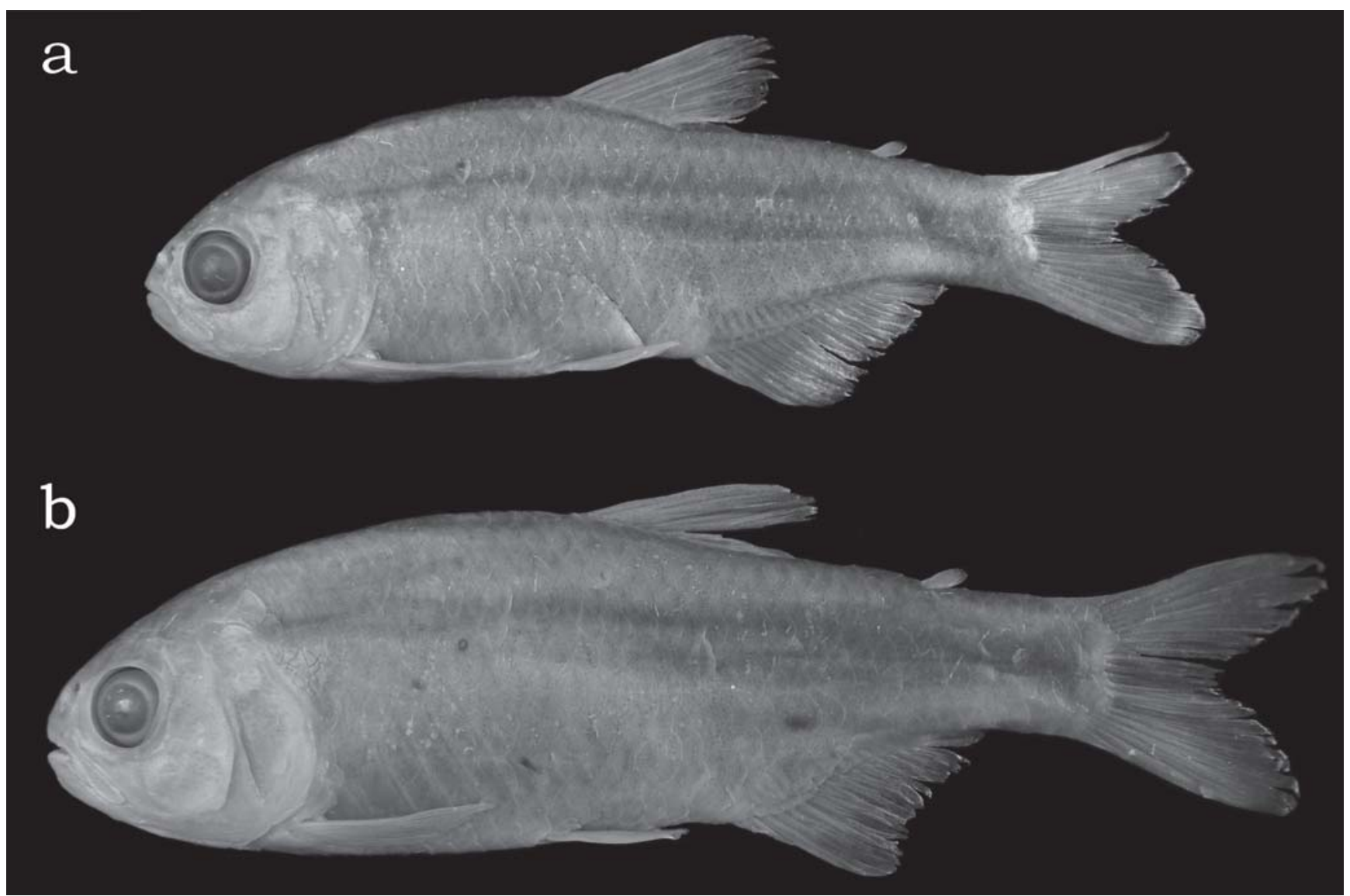

Fig. 1. Astyanax jordanensis, rio Jacu, rio Iguaçu basin, Candói, Paraná, Brazil. (a) MZUSP 99137, holotype, male, 47.7 mm SL. (b) NUP 1681, paratype, female, $56.7 \mathrm{~mm}$ SL. 
Casciotta \& Almirón, 2002], more lateral line scales [35-38 vs. 34-35 in A. jenynsii (Steindachner, 1877)], the possession of one humeral spot [vs. two in A. brachypterygium Bertaco \& Malabarba, 2001; A. cremnobates Bertaco \& Malabarba, 2001; A. leonidas; A. obscurus (Hensel, 1870); and A. rivularis (Lütken, 1875)], and the shape of the dentary teeth (abruptly decreasing in size after the fifth tooth $v$ s. teeth gradually decreasing in size posteriorly in A. intermedius Eigenmann, 1908). Astyanax jordanensis differs from A. microschemos Bertaco \& Lucena, 2006 by a smaller orbital diameter (22.6$29.1 \%$ vs. $29.7-34.1 \%$ of HL), a greater snout length (25.3$29.7 \%$ vs. $19.8-25.6 \%$ of HL), by having more predorsal scales (12-15 vs. 10-12); from A. paranae Eigenmann, 1914 by having a greater interorbital width (30.6-35.7\% vs. $25.8-30.3 \%$ of HL), and more branched anal-fin rays (13-17 vs. 17-22); from A. totae by a greater snout length (25.3-29.7\% vs. $14.6-24.1 \%$ of HL), by having more dorsal procurrent rays (10-12 vs. 7), and fewer maxillary teeth ( 1 or 2, usually 1 vs. 2 to 5 , usually 3 ); from $A$. varzeae (included in the $A$. scabripinnis species complex by Abilhoa \& Duboc, 2007) by the smaller orbital diameter (22.6-29.1\% vs. 30.9-44.5\% of HL), a greater snout length (25.3-29.7\% vs. 16.4-23.3\% of HL), by having more dorsal procurrent rays (10-12 vs. 8 or 10), fewer lateral line scales (35-38 vs. 37-42), and by the possession of one humeral spot (vs. two), and from A. burgerai (described and included in the A. scabripinnis species complex by Zanata \& Camelier, 2009) by presenting a conspicuous midlateral band from humeral region to caudal peduncle (vs. inconspicuous), more branched anal-fin rays (13-17 vs. 18-19), and more lateral line scales (35-38 vs. 31-34).

Table 1. Morphometric data of Astyanax jordanensis based on the holotype and paratypes. $\mathrm{N}=$ number of specimens analyzed, including holotype, $\mathrm{SD}=$ standard deviation, $\mathrm{m}=$ male, $\mathrm{f}=$ female.

\begin{tabular}{lcccccc}
\hline & Holotype & \multicolumn{5}{c}{ Range } \\
& male & $\mathrm{N}$ & Low & High & Mean & SD \\
\hline Standard length (mm) & 47.7 & - & 39.2 & 75.7 & - & - \\
& Percents of standard length & & & \\
Predorsal distance & 51.5 & 42 & 50.9 & 59.4 & 54.0 & 1.5 \\
Prepelvic distance & 46.7 & 42 & 46.7 & 54.9 & 49.6 & 1.6 \\
Prepectoral distance & 25.4 & 42 & 24.6 & 28.8 & 26.2 & 0.9 \\
Preanal distance & 63.3 & 42 & 63.3 & 73.3 & 67.0 & 2.0 \\
Body depth at dorsal-fin origin & 30.4 & 49 & 27.8 & 35.6 & 31.4 & 1.5 \\
Caudal peduncle depth & 12.2 & 42 & 10.9 & 13.7 & 12.0 & 0.5 \\
Caudal peduncle length & 14.6 & 42 & 13.7 & 16.8 & 15.5 & 0.7 \\
Anal-fin base & 24.8 & 42 & 17.8 & 24.8 & 21.6 & 1.6 \\
Dorsal-fin length (m) & 25.3 & 7 & 23.9 & 27.0 & 25.2 & 1.2 \\
Dorsal-fin length (f) & - & 42 & 21.2 & 25.1 & 23.0 & 1.0 \\
Pelvic-fin length (m) & 17.0 & 7 & 16.2 & 17.9 & 16.9 & 0.5 \\
Pelvic-fin length (f) & - & 42 & 12.7 & 14.8 & 13.8 & 0.6 \\
Pectoral-fin length (m) & 22.3 & 7 & 22.3 & 25.1 & 23.8 & 0.9 \\
Pectoral-fin length (f) & - & 42 & 17.8 & 23.1 & 19.7 & 1.1 \\
Head length & 28.3 & 49 & 25.8 & 31.7 & 28.6 & 1.2 \\
& Percents of head length & & & & \\
Snout length & 27.0 & 42 & 25.3 & 29.7 & 27.3 & 1.0 \\
Upper jaw length & 42.2 & 42 & 38.8 & 47.1 & 43.4 & 1.5 \\
Orbital diameter & 27.8 & 49 & 22.6 & 29.1 & 25.7 & 1.4 \\
Interorbital width & 32.8 & 42 & 30.6 & 35.7 & 33.0 & 1.1 \\
\hline
\end{tabular}

Description. Morphometric data for Astyanax jordanensis presented in Table 1. Body compressed and elongate; greatest body depth usually located anterior to dorsal-fin origin. Dorsal profile of body convex from snout to dorsal-fin origin, nearly straight along dorsal-fin base, straight or slightly concave from last dorsal-fin ray to adipose fin. Ventral profile of body convex from mouth to anal-fin origin, nearly straight along anal-fin base. Caudal peduncle elongate and nearly straight to slightly concave along both dorsal and ventral margins.

Head small. Mouth terminal, lower jaw slightly shorter than upper jaw. Maxilla extending posteriorly to vertical through middle of orbit, slightly curved, and forming angle of about 45 degrees relative to longitudinal body axis.

Premaxilla with two teeth rows, outer row with 3(7), 4*(28), or 5(2) teeth with three to five cusps. Inner premaxillary row with $5^{*}(40)$ teeth, symphysial teeth with four cusps, second and third teeth with four to seven cusps and two posterior most teeth smaller with three to five cusps. Maxilla with $1 *(25)$ or 2(14) teeth with three cusps. Dentary with the four anterior most teeth larger, with five to seven cusps. Large teeth of dentary followed by six to eight smaller teeth with one to three cusps, gradually decreasing in size. All teeth with central cusp longer than lateral cusps (Fig. 2). Gill rakers on dorsal limb of outer gill arch 6(3), and on ventral limb 10(2) or 11(1).

Dorsal-fin rays i,9(3), ii,9*(33); first unbranched ray shorter when present, approximately half length of second ray. Additional very small first ray, iii,9(6) observable only in c\&s and radiographed specimens. Dorsal-fin pterygiophores 10(2) or 11(1). Mature males with small bony hooks on distal onethird of first to fifth branched rays. Dorsal-fin origin posterior

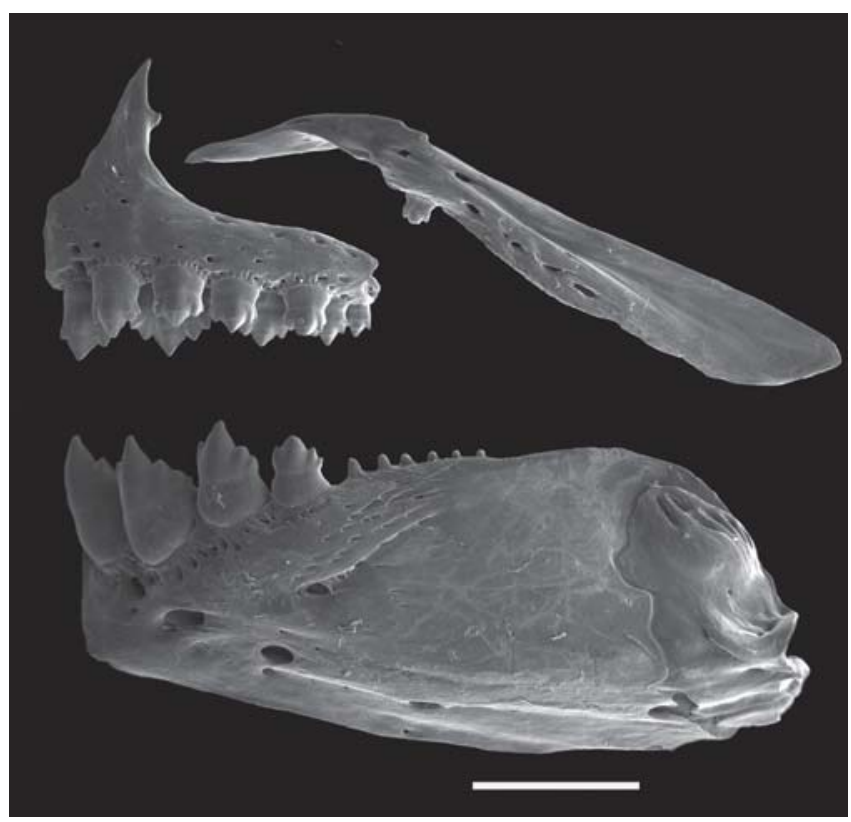

Fig. 2. Astyanax jordanensis, MCP 41915, paratype, $44.3 \mathrm{~mm}$ SL. Scanning electronic microscopy of left side of upper and lower jaws. Scale bar $=1 \mathrm{~mm}$. 
to middle of body, and posterior to vertical through pelvic-fin origin. Adipose fin small, located approximately at vertical through base of last anal-fin ray. Pectoral-fin rays i,9(6), i,10*(14), i,11(23), or i,12(2). Pectoral-fin origin situated anterior to posterior margin of opercle. Tip of pectoral fin reaching pelvic-fin origin in males, and reaching approximately three quarters of distance between pectoral- and pelvic-fin origins in females. Mature males with small bony hooks on distal portion of first to eighth branched rays. Pelvic-fin rays i,6*(34) or i,7(11). Pelvic fin of males usually bearing small bony hooks along ventromedial border of first to fourth branched rays. Pelvic-fin origin located anterior to vertical through dorsalfin origin. Tip of pelvic fin reaching anal-fin origin in males, falling short of that point in females. Anal-fin rays iii,14(3), iii,15(6), iii,16*(5), iv,13(1), iv,14(3), iv,15(7), iv,16(4), iv,17(2), v,13(1), v,14(3), v,15(5), v,16(3), v,17(2). Anal-fin pterigiophores $17(2)$ or 18(1). Anal-fin rays of mature males bearing one or two retrorse bony hooks along posterolateral border of each segment of lepidotrichia, usually along last unbranched ray to fifteen anterior branched rays. Anal-fin hooks more numerous along first to tenth branched rays and usually located along posterior most branch and distal one-half to two-thirds of length of each ray. Some mature females bearing few bony hooks on last unbranched ray and anterior branched anal-fin rays. Anal-fin origin located posterior to vertical through base of last dorsal-fin ray. Distal margin of anal fin concave in females, nearly straight in males. Caudal fin forked, lobes approximately similar in size, slightly pointed, with i,16,i(5) or $\mathrm{i}, 17, \mathrm{i}^{*}(35)$ rays. Dorsal procurrent caudal-fin rays 10(2), 11(6) or 12(3). Ventral procurrent caudal-fin rays 9(2) or 10(10).

Scales cycloid, moderately large. Lateral line complete, with 35(1), 36(7), 37*(16), or 38 (16) perforated scales. Scale series between dorsal-fin origin and lateral line 5(1), $6 *(40)$ or $7(1)$. Scale series between lateral line and pelvic-fin insertion $5 *(42)$. Predorsal scales $12(1), 13 *(14), 14(18)$ or 15(6) and regularly arranged. Circumpeduncular scales 13(11), 14*(25) or 15(5). Scale sheath along anal-fin base formed by five to seven scales in single series covering base of anterior most rays.

Total vertebrae 34(3), 35(1), 36(6) or 37(2), precaudal vertebrae 17(1), 18(8) or 19(3), caudal vertebrae 17(5), 18(5) or 19(1). Ribs 13(3). Supraneurals 4(5), 5(5) or 6(2).

Color in alcohol. Dorsal portion of head and body densely dark brown; dorsolateral portions of head and body brownish and lighter ventrally. Body with broad, blackish midlateral band from humeral region to caudal peduncle. Midlateral band expanded dorsally and ventrally into a dark lozenge shaped spot on caudal peduncle. Single, brown, narrow, sometimes inconspicuous vertically elongate humeral spot. Dorsal portion of spot slightly wider than ventral. Ventral limit of spot over first to second scale below lateral line and dorsal limit about two to three horizontal series of scales above lateral line. Fins with scattered dark chromatophores, mainly over distal third; pigmentation more obvious on median fins. Caudal fin with a faint dark pigmentation on middle rays.
Sexual dimorphism. Males of Astyanax jordanensis posses bony hooks on the dorsal-, pectoral-, pelvic-, and anal-fin rays, albeit with hooks less evident on the dorsal fin. Males and females also slightly differ in the proportions of the dorsal, pectoral, and pelvic fins (Table 1) and in the anal-fin shape, which is concave in females and nearly straight in males (Fig. 1). Mature females reach larger body sizes than mature males (44.3-75.7 mm vs. 34.2-47.7 mm SL, respectively). Twenty one mature female paratypes have a few small bony hooks on the last unbranched ray and anterior branched anal-fin rays, a character unusual in characids (see discussion for more details). Gill glands were not found in either males or females.

Distribution. All specimens were collected in the middle and upper portions of rio Jacu and rio das Torres in the lower portions of the rio Jordão drainage, lower rio Iguaçu basin, Paraná, Brazil (Fig. 3).

Etymology. The specific name jordanensis is in reference to the drainage from where the species is described, the rio Jordão, a tributary to the rio Iguaçu basin. An adjective.

Ecological notes. Stomach contents of four paratypes included aquatic insects (Epemeroptera; Hemiptera: an adult of Gerridae; Diptera: pupa, and larvae of Ceratopogonidae), terrestrial insects (adults of Diptera; Hymenoptera; Lepidoptera; and Coleoptera), and plant fragments (fruits of Gramineae; sporophytes and leaves of the Bryophyta).

\section{Discussion}

The diagnosis of Astyanax jordanensis was constructed comparing members of the $A$. scabripinnis species complex which fits all the characters delimited by Bertaco \& Lucena (2006). The species A. epiagos and A. jacobinae, recently

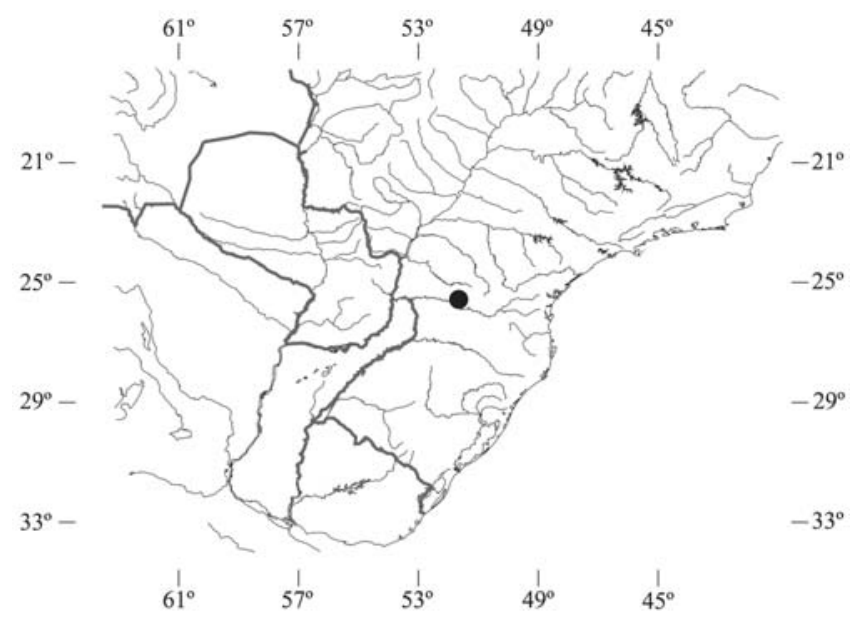

Fig. 3. Partial map of South America showing the distribution of Astyanax jordanensis (dot). The symbol represents more than one lot and locality. 
described and included in this complex by Zanata \& Camelier (2008), were not compared. To our understanding, they do not fit all the characters delimited for that complex since they lack the midlateral dark body stripe. However, other characters also differentiate $A$. jordanensis from these species, including a single series of five to seven scales covering base of anterior anal-fin rays and a reduced area of skin between infraorbitals and preopercle (vs. scales absent over anal-fin base and a broad area of skin in A. epiagos), and 13-17 branched anal-fin rays and dentary teeth abruptly decreasing in size after the fourth tooth (vs. 19-22 rays and teeth gradually decreasing in size posteriorly in A. jacobinae).

In addition to Astyanax jordanensis, there are six other congeners inhabiting the rio Iguaçu basin: A. altiparanae, $A$. gymnogenys, A. ita, A. leonidas, A. totae, and A. varzeae, along with at least six additional undescribed forms (Garavello et al., 1997).

The high degree of endemism of the ichthyofauna of rio Iguaçu is likely a consequence of the Iguaçu falls that are situated close to the mouth of the river into the rio Paraná (Garavello et al., 1997). Ingenito et al. (2004) recorded 41 fish species in the upper rio Iguaçu basin, of which eight were considered endemic. In the lower rio Iguaçu basin, Baumgartner et al. (2006) also recorded 41 fish species, but considered 19 endemic when compared to the upper portions of the basin, suggesting that there are regions of endemicity even within the rio Iguaçu basin. That hypothesis also applies to the rio Jordão drainage, from where six endemic species have already been described: Cnesterodon omorgmatos Lucinda \& Garavello, 2001; Jenynsia diphyes Lucinda, Ghedotti \& Graça, 2006; Trichomycterus crassicaudatus Wosiacki \& de Pinna, 2008; T. igobi Wosiacki \& de Pinna, 2008; T. plumbeus Wosiacki \& Garavello, 2004 and T. taroba Wosiacki \& Garavello, 2004. Lucinda et al. (2006) attribute this endemism to a 15 meter high waterfall that was close to the mouth of the rio Jordão, and which may restrict fish dispersal between the rio Jordão drainage and the remaining portions of the rio Iguaçu basin. This waterfall, the Vaca Branca, is now submerged under a reservoir. Astyanax jordanensis similarly seems to be endemic to this drainage.

Mature males of Astyanax jordanensis possess bony hooks on all fin rays except the caudal fin. Presence, shape, and number of hooks in different fins have been considered synapomorphic for several groups in the Characidae (Malabarba \& Weitzman, 2003), but with hooks usually found only on the anal and pelvic fins, and sometimes on the caudal fin of males. Recently, Gonçalves et al. (2005) observed a positive correlation between the mean gonadossomatic index and the number of anal-fin rays bearing hooks in mature males of Aphyocharax anisitsi Eigenmann \& Kennedy, 1903. They suggested that those hooks develop with testis maturation, and once developed they are retained by the males.

The occurrence of bony hooks on all fin rays is uncommon among characids. Among Astyanax species, the presence of bony hooks on all fin rays is known to occur in Astyanax aramburui Protogino, Miquelarena \& López, 2006; A. chico
Casciotta \& Almirón, 2004; A. hermosus Miquelarena, Protogino \& López, 2005; A. ojiara, A. pynandi Casciotta, Almirón, Bechara, Roux \& Ruiz Diaz, 2003 and A. troya. Hooks occur on all fin rays except the dorsal fin in A. leonidas and except the pectoral fin in A. tumbayaensis Miquelarena \& Menni, 2005 (Protogino et al., 2006).

It is noteworthy that most of examined mature females of A. jordanensis also posses a few small bony hooks on the last unbranched and first and second branched anal-fin rays, an unusual character in the Characidae. Among characids, bony hooks on pelvic-fin rays in females have been recorded only for the species of the genus Cheirodon Girard, 1855, in which they are considered a synapomorphic character by Malabarba (1998). According to that author, those bony hooks are not as developed in size as those of males, and sometimes they are visible only in large females, as is the case in A. jordanensis. Bony hooks on fins, longer pectoral- and pelvic-fin rays, straight shape of anal-fin profile, and smaller body sizes are secondary sexual dimorphic characters usually reported for males in the genus Astyanax. The presence of bony hooks in females of $A$. jordanensis might have several causes: masculinization, a natural endocrine variation, or it could be considered an autapomorphic character for this species. However, more detailed studies are needed in order to corroborate any of these alternative hypotheses. Previously, no other Astyanax has been described with bony hooks on anal-fin rays in females.

Comparative material examined. Astyanax species B to G from the rio Iguaçu basin follow Garavello et al.(1997). In addition to the comparative material listed in Bertaco \& Lucena (2006), the following specimens were analyzed: Brazil: Goiás: A. aff. paranae: NUP 1366, 16, 27.2-55.3 mm SL, córrego Capão do Chico, upper rio Paraná basin. Minas Gerais: A. turmalinensis: DZUFMG 16, 8 of 32, 33.3-64.8 mm SL, paratypes, ribeirão do Gigante, rio Jequitinhonha basin. Paraná: A. altiparanae: NUP 583, 14, 72.3-98.5 mm SL, Jordão Reservoir, rio Iguaçu basin. A. gymnogenys: NUP 2037, 1, 115.2 mm SL, Foz do Areia Reservoir, rio Iguaçu basin. A. aff. fasciatus: NUP 4815, 7, 61.2-90.2 mm SL, rio Atlântico, upper rio Paraná basin. A. paranae: CAS 22555, holotype, 113.4 mm SL, Paraná State; NUP 756, 177, 63.2-98.2 mm SL, rio Pitangui, upper rio Paraná basin. A. totae: NUP 4099, 16, 41.9-56.3 mm SL, paratypes, rio Cascata, rio Iguaçu basin. A. varzeae: MHNCI 9147, 15, 44.4-82.8 mm SL, paratypes, rio da Várzea, rio Iguaçu basin. Astyanax sp.: NUP 3048, 22, 39.2-93.3 mm SL, arroio Laranjal, rio Iguaçu basin. Astyanax sp. B: NUP 3051, 32, 25.3-62.2 mm SL, arroio Laranjal, rio Iguaçu basin. Astyanax sp. C: NUP 2782, 6, 68.8-91.4 mm SL, Salto Santiago Reservoir, rio Iguaçu basin. Astyanax sp. D: NUP 2045, 4, 67.4-93.6 mm SL, rio Iguaçu. Astyanax sp. E: NUP 2046, 3, 53.0-78.7 mm SL, rio Iguaçu. Astyanax sp. F: NUP 3699, 3, 80.6-98.6 mm SL; NUP 4063, 1, 98.4 mm SL, Jordão Reservoir, rio Iguaçu basin. Astyanax sp. G: NUP 1580, 9, 74.5143.7 mm SL, Jordão Reservoir, rio Iguaçu basin.

\section{Acknowledgements}

We are grateful to Weferson J. da Graça for helping with the clearing and staining process and critical comments, 
Marlene R. da Silva for identifying stomach contents, Harumi I. Suzuki and Dayani Bailly for identifying sex stages, Dirceu Baumgartner for providing specimens, and to the Centro de Microscopia e Microanálises (CEMM), PUCRS for the SEM preparations. We thank Nupélia for logistical support, and Copel for collecting the material. The Conselho Nacional de Desenvolvimento Científico e Tecnológico (CNPq) provided financial support to HSVA during his Master course (Proc. 190417/2006-4), and to CSP (Proc. 311975/2006-2). HSVA was benefited by the Programa de Estudantes Convênio de PósGraduação (PEC-PG). VAB is financed by a postdoctoral fellowship from CNPq (Proc. 150042/2009-4), and is grateful for the fellowship from the California Academy of Sciences, CAS.

\section{Literature Cited}

Abilhoa, V. \& L. F. Duboc. 2007. A new species of the freshwater fish genus Astyanax (Ostariophysi: Characidae) from the rio Iguaçu basin, southeastern Brazil. Zootaxa, 1587: 43-52.

Baumgartner, D., G. Baurmgartner, C. S. Pavanelli, P. R. L. Silva, V. A. Frana, L. C. Oliveira \& M. R. Michelon. 2006. Fish, Salto Osório Reservoir, Iguaçu River basin, Paraná State, Brazil. Check List, 2(1): 1-4.

Bertaco, V. A. \& C. A. S. Lucena. 2006. Two new species of Astyanax (Ostariophysi: Characiformes: Characidae) from eastern Brazil, with a synopsis of the Astyanax scabripinnis species complex. Neotropical Ichthyology, 4(1): 53-60.

Bertaco, V. A. \& L. R. Malabarba. 2001. Description of two new species of Astyanax (Teleostei: Characidae) from headwater streams of Southern Brazil, with comments on the " $A$. scabripinnis species complex”. Ichthyological Exploration of Freshwaters, 12(3): 221-234.

Eigenmann, C. H. 1921. The American Characidae. Memoirs of the Museum of Comparative Zoology, 43(3): 209-310.

Eigenmann, C. H. 1927. The American Characidae. Memoirs of the Museum of Comparative Zoology, 43(4): 311-428.

Fink, W. L. \& S. H. Weitzman. 1974. The so-called cheirodontin fishes of Central America with descriptions of two new species (Pisces: Characidae). Smithsonian Contributions to Zoology, 172: 1-46.

Garavello, J. C., C. S. Pavanelli \& H. I. Suzuki. 1997. Caracterização da ictiofauna do rio Iguaçu. Pp. 61-84. In: Agostinho, A. A. \& L. C. Gomes (Eds.). Reservatório de Segredo: bases ecológicas para o manejo. Maringá, Eduem, 387p.

Gonçalves, T. K., M. A. Azevedo, L. R. Malabarba \& C. B. Fialho. 2005. Reproductive biology and development of sexually dimorphic structures in Aphyocharax anisitsi (Ostariophysi: Characidae). Neotropical Ichthyology, 3(3): 433-438.

Ingenito, L. F. S., L. F. Duboc \& V. Abilhoa. 2004. Contribuição ao conhecimento da ictiofauna da bacia do Alto rio Iguaçu, Paraná, Brasil. Arquivos de Ciências Veterinárias e Zoologia da Unipar, 7(1): 23-36.

Lima, F. C. T., L. R. Malabarba, P. A. Buckup, J. F. P. Silva, R. P. Vari, A. Harold, R. Benine, O. T. Oyakawa, C. S. Pavanelli, N. A. Menezes, C. A. Lucena, M. C. S. L. Malabarba, Z. M. S. Lucena, R. E. Reis, F. Langeani, L. Casatti, V. A. Bertaco, C. Moreira \& P. H. F. Lucinda. 2003. Genera Incertae Sedis in Characidae. Pp. 106-169. In: Reis, R. E., S. O. Kullander \& C. Ferraris (Eds.). Check list of the freshwater fishes of South and Central America. Porto Alegre, Edipucrs, 729p.
Lucinda, P. H. F., M. J. Ghedotti \& W. J. Graça. 2006. A new Jenynsia species (Teleostei, Cyprinodontiformes, Anablepidae) from southern Brazil and its phylogenetic position. Copeia, 2006: 613-622.

Malabarba, L. R. 1998. Monophyly of the Cheirodontinae, characters and major clades (Ostariophysi: Characidae). Pp. 193-233. In: Malabarba, L. R., R. E. Reis, R. P. Vari, Z. M. S. Lucena \& C. A. S. Lucena (Eds.). Phylogeny and classification of Neotropical fishes. Porto Alegre, Edipucrs, 603p.

Malabarba, L. R. \& S. H. Weitzman. 2003. Description of new genus with six new species from southern Brazil, Uruguay and Argentina, with a discussion of a putative characid clade (Teleostei: Characiformes: Characidae). Comunicações do Museu de Ciências e Tecnologia da PUCRS, Série Zoologia, 16(1): 67-151.

Protogino, L. C., A. M. Miquelarena \& H. L. López. 2006. A new species of Astyanax (Teleostei, Characiformes, Characidae), with breeding tubercles, from the Paraná and Uruguay river basins. Zootaxa, 1297: 1-16.

Rosen, D. E. 1972. Origin of the characid fish genus Bramocharax and a description of a second, more primitive, species in Guatemala. American Museum Novitates, 2500: 1-21.

Taylor, W. R. \& G. C. Van Dyke. 1985. Revised procedures for staining and clearing small fishes and other vertebrates for bone and cartilage study. Cybium, 9: 107-119.

Zanata, A. M. \& P. Camelier. 2008. Two new species of Astyanax (Characiformes: Characidae) from upper rio Paraguaçu and rio Itapicuru basins, Chapada Diamantina, Bahia, Brazil. Zootaxa, 1908: 28-40.

Zanata, A. M. \& P. Camelier. 2009. Astyanax vermilion and Astyanax burgerai: new characid fishes (Ostariophysi: Characiformes) from Northeastern Bahia, Brazil. Neotropical Ichthyology, 7(2): 175-184.

Accepted April 2009 Published June 17, 2009 